\title{
Eräs stabiilin väestön ja Eilert Sundtin lain matemaattinen tulkinta ${ }^{1}$
}

\author{
Fil. kand. HEIKKI LAUTKARI
}

Tilastollinen päätoimisto

\section{Demografinen tausta ${ }^{2}$}

\subsection{Kuolleisuus- ja eloonjäämistaulu}

Demografisen mittauksen ehkä suurimmat ponnistelut on suoritettu kuolleisuuden tutkimisessa. Tämä oli ensimmäinen demografian ala, joka joutui perusteellisen analyysin kohteeksi ja on löytänyt kaupallisia sovellutuksia vakuutusalalla.

Kuolleisuutta esitetään perinteellisesti kuolleisuus- ja eloonjäämistaululla, joka lasketaan jollakin aikavälillä (usein 5 tai 10 vuotta) todetun kuolleisuuden perusteella. Tarkkuutensa ja selvyytensä perusteella se on eräs havainnollisimmista väestöilmiöiden mittaamiskeinoista. Sillä on tärkeä merkitys muussakin kuin kuolleisuuden tutkimisessa.

Kuolleisuus- ja eloonjäämistaulu on asteittain kuolemantapausten johdosta pienenevä hypoteettisen ihmisryhmän eli hypoteettisen kohortin elämäntarina. Taulu alkaa jokaisen jäsenen syntymästä ja jatkuu, kunnes kaikki jäsenet ovat kuolleet. Kohortti on sellainen kuviteltu joukko samanikäisiä henkilöitä, joka noudattaa seuraavia yksinkertaistavia olettamuksia:

a. Kohorttiin ei muuta uusia jäseniä sen ulkopuolelta, eikä kohortista muuta jäseniä sen ulkopuolelle. Ainoat jäsenmäärän muutokset aiheutuvat kuolemantapauksista. Kohortti muodostaa siis suljetun väestön.

b. Ihmiset kuolevat kussakin iässä ennakolta määrätyn ja muuttumattoman kaavion mukaan.

c. Kohortti saa alkunsa normeeratusta syntyneiden määrästä (aina jokin tasaluku, kuten 1000,10000 tai 100000 ), jota kutsutaan taulun juureksi. Tämä normeeraus tekee mahdolliseksi vertailun erilaisten kuol-

1 Esitys on referaatti tekijän matemaattisluontoisesta tilastotieteen laudatur-tutkielmasta. Aiheen olen saanut prof. G. Elfvingiltä, jolta myös olen saanut arvokkaita neuvoja työn kuluessa.

2 Kohdat 1.1., 1.2. A ja 1.2 B. perustuvat pääasiassa Barclay'n teokseen Techniques of Population Analysis (Princeton, N.J., 1958). 
leisuus- ja eloonjäämistaulujen välillä. Myös syntyneistä määrätyssä iässä elossa olevien suhteellinen osuus ilmenee yhdellä silmäyksellä itse taulusta. Jos esimerkiksi 10000 jäsenen kohortista 5420 oli elossa 67 vuoden iässä, merkitsee se, että täsmälleen $54.2 \%$ saavutti mainitun iän.

d. Joka iässä (lukuun ottamatta ensimmäisiä elinvuosia) kuolemantapaukset ovat tasaisesti jakautuneet kahden peräkkäisen syntymäpäivän välille. Toisin sanoen puolet odotetuista kuolemantapauksista esimerkiksi 9 ja 10 vuoden välillä tapahtuu ennen 9.5 vuoden ikää.

e. Kohortti sisältää tavallisesti vain yhden sukupuolen jäseniä. On mahdollista konstruoida molempien sukupuolien yhteinen taulu, mutta ero naisten ja miesten kuolleisuuden välillä on useimmissa ikäluokissa niin huomattava, että erillinen käsittely on perusteltua.

\subsection{Kuolleisuus- ja eloonjäämistauluun perustuvia hypoteettisia malleja}

\subsection{A. Stationäärinen väestö}

Kohdassa 1.1. kuolleisuus- ja eloonjäämistaulu määriteltiin samana ajanjaksona syntyneiden ihmisten hypoteettisena kohorttina, joka menettää ennakolta määrätyn osan väestöstään kussakin iässä. Siitä ilmenee vakiomäärästä (esim. 100 000) syntyneitä kussakin tarkassa iässä x elossa olevien kohortin jäsenten lukumäärä $\mathrm{l}_{\mathrm{x}}$. Soveltamalla olettamusta d kohdan 1.1. lopussa, saadaan laskemalla kahden peräkkäisen $1_{\mathrm{x}}$-luvun keskiarvo $\left(\mathrm{L}_{\mathrm{x}}=\frac{\mathrm{l}_{\mathrm{x}}+\mathrm{l}_{\mathrm{x}+1}}{2}\right.$, paitsi ensimmäisille ikävuosille, jolloin kaava on hieman toisenlainen) $\mathrm{x}$ ja $(\mathrm{x}+1)$ vuoden iän välillä elossa olevien kohorttiin kuuluvien henkilöiden keskimääräinen lukumäärä. Suorittamalla tämä laskelma kaikille 1-vuotisikäväleille saadaan taulukko, joka muistuttaa jonakin vuonna suoritetusta väestölaskennasta saatua väestön ikäryhmitystä. Saraketta $L_{x}$ voidaan siten yhtä hyvin pitää erään määrätyn ajankohdan väestönä kuin kohorttina, jota seurataan peräkkäin kussakin iässä.

Tarkastelemme seuraavassa toisin sanoen hypoteettista väestöä, jossa vallitsee kuolleisuus- ja eloonjäämistauluissa esitetty kuolleisuus, ja jonka ikäjakautuma ja syntyneisyys tietyllä alkuajankohdalla ovat sellaiset, että yhdessä vuodessa syntyy tasan kuolleisuus- ja eloonjäämistaulun edellyttämä yksilölukumäärä (esim. 100000$)$. Jokainen tämän väestön vuosiluokka tulee olemaan kohortti, joka ajan kuluessa pienenee taulukon ilmoittamalla tavalla, ja jokaisella ajankohdalla tulevat eri ikäluokat olemaan kuolleisuus- ja eloonjäämistaulun lukujen mukaiset. Tällaista suljettua väestöä sanotaan stationääriseksi väestöksi eli vakioväestöksi; kuolleisuus- ja eloonjäämistaulun sarake $\mathrm{L}_{\mathrm{x}}$ on samalla stationäärisen väestön 
ikäjakautumataulukko. ${ }^{1}$ Tähdennämme vielä, että stationäärinen väestö edellyttää syntyneisyyden olevan kuolleisuuden kanssa tasapainossa.

\subsection{B. Stabiili väestö}

Stationäärisessä väestössä jokainen kohortti alkaa samasta syntyneiden määrästä (100 000 tai yleisesti $l_{0}$ kuolleisuus- ja eloonjäämistaulussa). Jos sen sijaan syntyneiden määrän oletetaan kasvavan tai vähenevän kohortista toiseen vakioprosentin verran, saadaan ns. stabiili väestö ${ }^{2}$. Tällöin tarkalleen $\mathrm{x}$-vuotiaiden määrä väestössä on $1_{\mathrm{x}} \varrho^{-\mathrm{x}}$, missä $\varrho$ on kasvu- tai vähenemiskerroin. Jos syntyneiden määrä kasvaa kohortista toiseen $(\varrho>1)$, saadaan ns. progressiivinen väestö, jos se taas pienenee $(\varrho<1)$, saadaan ns. regressiivinen väestö. Stationäärinen väestö on itse asiassa stabiili väestö $\varrho: n$ arvolla 1 .

Kasvu- tai vähenemiskerroin voidaan, kuten kohdassa 3.2. tulemme näkemään, kullakin ajankohdalla määrätä todellisen väestön syntyneisyyden ja kuolleisuuden perusteella, ja näin saadun $\varrho: n$ arvon sekä kuolleisuus- ja eloonjäämistaulun perusteella voidaan laskemalla «konstruoida stabiili väestö, joka parhaalla mahdollisella tavalla liittyy todellisen väestön kehitystendenssiin tarkasteltuna ajankohtana.

Stabiili väestö vaikuttaa sellaisenaan määriteltynä enemmän tai vähemmän keinotekoiselta mallilta. Se saa kuitenkin luonnollisen sisällön, kun kohdassa 2 osoitamme, että se on odotettu rajamuoto, jota jokainen suljettu ${ }^{3}$ naispuolinen väestö rajattomasti lähenee, jos sen hedelmällisyys ja kuolleisuus ikäluokittain pysyy samansuuruisena. Korostettakoon jo tässä yhteydessä, että seuraavassa esitettävää teoriaa voidaan, tarvittaessa modifikatioin, soveltaa myös muihin biologisiin väestöihin tai jopa epäorgaanisiin populaatioihin.

\subsection{Eilert Sundtin laki}

Monista väestönkehitystä koskevista teorioista, joita väestöteorian historian aikana on esitetty, on luonteeltaan ehkä kaikkein matemaattisin Eilert Sundtin laki, joskin sen ensimmäinen keksijä norjalainen pappi ja yhteiskuntaolojen tutkija Eilert Sundt $(\dagger 1875)$ esitti sen täysin empiirisenä havaintona. Ruotsissa ja Suomessa ovat vastaavia tutkimuksia suorittaneet mm. Sundbärg (1907) ja O. K. Kilpi (1913). Lisäksi on mainittava saksalainen Lösch (1936). "Selvitellessään syitä siihen, miksi Norjassa 1840-

1 Seuraavassa emme enää palaa $1_{x}: n$ ja $L_{x}: n$ väliseen yhteyteen, vaan puhumme ainoastaan $1_{x}$ :stä tai sen teoreettisesta vastineesta $r_{x}$.

2 Tämäkin yleisempi väestö on suljettu, koska sen muutokset perustuvat vain uusien jäsenten syntymiseen ja vanhojen kuolemiseen.

3 Kun seuraavassa esityksessämme puhumme väestöstä, tarkoitamme ilman muuta, että se myös on suljettu. 
luvulla solmittiin poikkeuksellisen paljon avioliittoja, Sundt huomasi, että noin kolmisenkymmentä vuotta aikaisemmin avioliittojen luku niinikään oli ollut huomattavan suuri ja siitä johtuen syntyneisyyskin korkea. Näiden huomioittensa nojalla Sundt päätteli, että suurinta syntyvyyttä edustavilta ajanjaksoilta peräisin olevat ikäpolvet säilyvät väestössä suhteellisen väkirikkaina ikäkaudesta toiseen, samoin kuin alhaisilta syntyvyyskausilta lähtevät ikäpolvet pysyvät vajaväkisinä halki elämän. Tullessaan avioliittoikään väkirikkaat ikäpolvet saattavat antaa aiheen uuteen avioliittojen ja syntyvyyden nousukauteen, vajaväkiset polvet taas vastaavaan laskukauteen. Tätä demografisten jaksojen toistumista on sittemmin nimitetty Eilert Sundtin laiksi.« (Lento, 1955, s. 54-55.)

Yleispätevää matemaattista tulkintaa Eilert Sundtin laille lienee vaikeaa esittää. Sen sijaan voidaan - kuten kohdasta 3.2. ilmenee - siinä yksinkertaisessa epärealistisessa erikoistapauksessa, että annettu naispuolinen lähtöväestö kehittyy kiinteiden ikäluokittaisten hedelmällisyys- ja kuolleisuuslukujen mukaan, osoittaa, että lähtöväestön ikäluokittaiset poikkeamat stabiilista väestöstä aiheuttavat lyhyellä tähtäimellä likimääräisesti jaksollista ja vaimenevaa poikkeamaa syntyneiden odotetun lukumäärän stabiilista kasvulaista.

\section{Matemaattinen teoria ${ }^{1}$}

\subsection{Tarvittavien muuttujien ja parametrien määrittely}

Kuten kohdan 1.2.B. lopussa huomautimme, voidaan esillä olevaa matemaattista teoriaa sopivin modifikaatioin soveltaa jonkun biologisen väestön uutta väestöä synnyttävän osan muutoksiin. Ottaen huomioon sovellutuksen kohdassa 3.2. sovimme kuitenkin ja tässä vaiheessa, että seuraavissa määritelmissä on kysymyksessä naispuolinen ihmisväestö ja siitä syntyvä uusi naispuolinen ihmisväestö sekä että riittävän suuri miespuolinen väestö on olemassa. Aikayksikkönä käytämme normaalin demografisen käytännön mukaan yhtä vuotta.

Asetamme seuraavat määritelmät:

2.1.1. $\mathrm{v}_{\mathrm{k}}(\mathrm{o})=\mathrm{k}$-vuotiaiden ${ }^{2}$ lukumäärä ensimmäisen kalenterivuoden alussa $(0 \leqq \mathrm{k} \leqq \omega$, missä $\omega$ on korkein ikä, minkä väestöön kuuluva nainen voi saavuttaa)

1 Esitettävä stabiilin väestön teoria on jo vanhastaan tunnettu. A. J. Lotka on hieman toisin kuin kirjoittaja käsitellyt sitä artikkeleissaan. Sitäpaitsi on maassamme prof. Leo Törnqvist käsitellyt tähän aihepiiriin liittyvien väestötilastollisten laskelmien teoriaa yleisemmässä muodossa.

2 Iällä $\mathrm{k}$ vuotta tarkoitetaan ikää $1 / 2$ vuotta $\mathrm{k}$ :nnen syntymäpäivän molemmin puolin (poikkeus: Ikä 0 vuotta, jolla tarkoitetaan ikää syntymähetken ja $1 / 2$ vuoden iän välillä). 
2.1.2. $\mathrm{v}_{\mathrm{k}}(\mathrm{n})=\mathrm{k}$-vuotiaiden odotettu lukumäärä kalenterivuoden $\mathrm{n}$ lopussa

2.1.3. $\mathrm{b}_{\mathrm{n}}=$ alkuperäiseen väestöön kuuluville äideille kalenterivuonna n syntyneiden odotettu lukumäärä

2.1.4. $\mathrm{u}_{\mathrm{n}}=$ kaikkien kalenterivuonna $\mathrm{n}$ syntyneiden odotettu lukumäärä

2.1.5. $\beta_{\mathrm{k}} \quad=$ todennäköisyys sille, että $\mathrm{k}$-vuotias nainen saa tyttölapsen

2.1.6. $\mathrm{a}_{\mathrm{i}}=$ todennäköisyys syntymähetkellä sille, että nainen kuolee i-vuotiaana

2.1.7. $\mathrm{r}_{\mathrm{k}}=\stackrel{\omega}{\Sigma} \mathrm{a}_{\mathrm{i}}=$ todennäköisyys syntymähetkellä sille, että nai$\mathrm{i}=\mathrm{k}+1 \quad$ nen on elossa $\mathrm{k}$-vuotiaana

2.1.8. $\mathrm{c}_{\mathrm{k}}=\mathrm{r}_{\mathrm{k}} \beta_{\mathrm{k}}=$ todennäköisyys syntymähetkellä saada tyttölapsi k-vuoden iässä

Esitetyt määritelmät vaikuttavat (määritelmiä 2.1.1.-4. lukuunottamatta) hieman monimutkaisilta. Näillä kaikilla on kuitenkin demografiassa yleisesti tunnetut vastineet. Niinpä $\beta_{\mathrm{k}}$ vastaa $\mathrm{k}$-vuotiaiden bruttoerikoishedelmällisyyslukua, $\mathrm{a}_{\mathrm{i}}$ kuolemanvaaralukua, $\mathrm{r}_{\mathrm{k}}$ k-vuotiaana elossa olevien lukua kuolleisuus- ja eloonjäämistaulun mukaan, $\mathrm{c}_{\mathrm{k}}$ netto-erikoishedelmällisyyslukua.

2.2. Syntyneiden odotusarvon asymptoottinen suhtautuminen. Väestön ikäjakautuman stabiilin rajamuodon olemassaolo ja pysyvyys

Tekemällä määrättyjä olettamuksia voidaan todennäköisyyslaskennan avulla johtaa seuraava palautusyhtälö kalenterivuonna n syntyneiden odotetulle lukumäärälle $u_{n}$ :

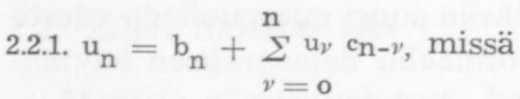

2.2.2. $\mathrm{b}_{\mathrm{n}}=\sum_{\mathrm{k}=\mathrm{o}}^{\infty} \mathrm{v}_{\mathrm{k}}(\mathrm{o}) \frac{\mathrm{c}_{\mathrm{k}}+\mathrm{n}}{\mathrm{r}_{\mathrm{k}}}$

Lähempi tarkastelu osoittaa, että viimeksi esitetyt yhtälöt vastaavat täysin väestöprognoosissa tavallisimmin käytettyä laskumenettelyä, kun oletetaan ikäluokittaisten syntyneisyys- ja kuolleisuuslukujen pysyvän samansuuruisina ennustekaudella.

Niin ikään voidaan johtaa seuraavat yhtälöt, joiden avulla määräytyy $\mathrm{k}$-vuotiaiden odotettu lukumäärä $\mathrm{v}_{\mathrm{k}}(\mathrm{n})$ kalenterivuoden $\mathrm{n}$ lopussa.

2.2.3. $\mathrm{v}_{\mathrm{k}}(\mathrm{n})=\mathrm{u}_{\mathrm{n}-\mathrm{k}} \mathrm{r}_{\mathrm{k}}(\mathrm{k}<\mathrm{n})$

2.2.4. $\mathrm{v}_{\mathrm{k}}(\mathrm{n})=\mathrm{v}_{\mathrm{k}}(\mathrm{o}) \frac{\mathrm{r}_{\mathrm{k}}}{\mathrm{r}_{\mathrm{k}-\mathrm{n}}} \quad(\mathrm{k} \geqq \mathrm{n})$ 
Yhtälö 2.2.3. edustaa ennustekaudella syntyneistä kalenterivuoden $\mathrm{n}$ lopussa elossa olevien lukua, yhtälö 2.2.4. alkuperäiseen väestöön kuuluvien vastaavaa lukua.

Pitäen yhtälöitä 2.2.1.—4. lähtökohtana voidaan oleellisesti todennäköisyyslaskennan emäfunktiomenetelmää käyttäen todistaa oikeiksi seuraavat perustavaa laatua olevat lauseet:

Lause 1

Väestön ikäjakautuma

$$
\mathrm{v}_{0}(\mathrm{o}), \mathrm{v}_{1}(\mathrm{o}), \mathrm{v}_{2}(\mathrm{o}), \ldots \ldots, \mathrm{v}_{\omega}(\mathrm{o})
$$

määrätyn lähtövuoden alussa, hedelmällisyysluvut ${ }^{1} c_{m}, c_{m+1}, \ldots, c_{m}+p^{2}$ ja eloonjäämisluvut $r_{0}, r_{1}, \ldots, r_{\omega}$ olkoot annetut. Oletamme, että seuraavina kalenterivuosina syntyneiden ja kuolleiden odotetut lukumäärät määräytyvät lähtöväestön ikäjakautuman ja annettujen hedelmällisyys- sekä eloonjäämislukujen mukaan. Jos ajattelemme näin määritellyn väestön kehitysprosessin jatketuksi äärettömiin (n kasvaa rajatta), lähenee lauseke $\frac{u_{n}}{\varrho^{n}}$ vakiota $C$ ja lauseke $\frac{v_{k}(n)}{\varrho^{n}}$ lauseketta $\mathrm{Cr}_{k} \varrho^{-k}$, missä C on lähtöväestön ikäjakautuman ja annettujen hedelmällisyys- sekä eloonjäämislukujen yksikäsitteisesti määräämä vakio. Tämä saadaan yhtälöstä

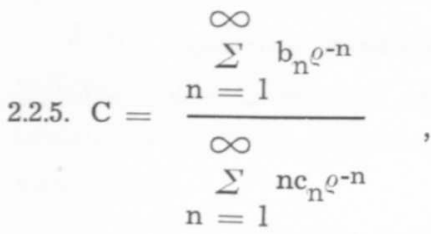

missä $\frac{1}{\varrho}$ on yhtälön

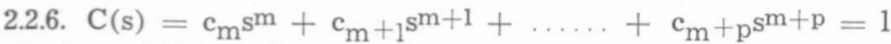
pienin positiivinen juuri. ${ }^{3}$

\section{Lause 2}

Väestön ikäjakautuma määrätyn lähtövuoden alussa olkoon stabiili 2.2.7. $\mathrm{Cr}_{0}, \mathrm{Cr}_{1} \varrho^{-1}, \mathrm{Cr}_{2} \varrho^{-2}, \ldots \ldots, \mathrm{Cr}_{\omega \varrho^{-\omega}}$, missä C kuten seuraavassakin on vakio ja @ määritelty kuten lauseessa 1. Siinä esiintyvät hedelmällisyysluvut $c_{m}, c_{m+1}, \ldots \ldots, c_{m+p}$ ja eloonjäämisluvut $r_{0}, r_{1}, \ldots \ldots$, $\mathrm{r}_{\omega}$ olkoot annetut. Oletamme, että seuraavina kalenterivuosina syntyneiden ja kuol-

1 Oikeastaan tässä pitäisi puhua vastaavista todennäköisyyksistä, mutta sovellutusten kannalta on mukavampi käyttää demografista terminologiaa.

2 Matemaattinen teoria vaatii lisäksi, että lukujono $\mathrm{c}_{\mathrm{m}}, \ldots, \mathrm{c}_{\mathrm{m}}+\mathrm{p}$, missä $\mathrm{m}$ on alhaisin ja $\mathrm{m}+\mathrm{p}$ korkein hedelmällinen ikävuosi, on jaksoton. Tällä teoreettisella ehdolla ei kuitenkaan kohdassa 3.2. esitettävän sovellutuksen kannalta ole mitään merkitystä.

$3 \varrho$ on Lotkan määrittelemä luonnollisen kasvun vakio. Koska yhtälön 2.2.6. vasempana puolena esiintyvä polynomi $\mathrm{C}(\mathrm{s})$ s:n arvolla 1 on sama kuin muodollisesta demografiasta tunnettu nettouusiutumisluku, on $\varrho \geqq 1$ riippuen siitä, onko nettouusiutumisluku $\gtreqless 1$ (samat merkit epäyhtälöissä voimassa yht'aikaa). 
leiden odotetut lukumäärät määräytyvät lähtöväestön ikäjakautuman ja annettujen hedelmällisyys- sekä eloonjäämislukujen mukaan. Tällöin tulee $u_{n}$ olemaan tarkkaan yhtäkuin lauseke $\mathrm{C} \varrho \mathrm{n}$, ja väestön ikäjakautuma vuoden $\mathrm{n}$ lopussa tulee pysymään stabiilina ja yhtäkuin

2.2.8. $\mathrm{Cr}_{0} \varrho^{\mathrm{n}}, \mathrm{Cr}_{1} \varrho^{\mathrm{n}-1}, \ldots \ldots, \quad \mathrm{Cr}_{\omega} \varrho^{\mathrm{n}-\omega}$.

Lause 1 ilmaisee lyhyesti sanottuna sen tosiseikan, että väestön ikäjakautuma hedelmällisyys- ja eloonjäämislukujen pysyessä muuttumattomina lähenee rajamuotoa, joka on riippumaton lähtöväestön ikäjakautumasta. ${ }^{1}$ (Vakio $\mathrm{C}$ on yhteisenä tekijänä kaikissa luvuissa $\mathrm{Cr}_{\mathrm{k}} \varrho^{-\mathrm{k}}$, eikä siis vaikuta ikäluokkien keskinäisiin suhdelukuihin).

Sitäpaitsi lauseesta 1 ilmenee, että lauseke $\frac{u_{n}}{\varrho^{n}}$ yllämainituilla edellytyksillä lähestyy vakiota $\mathrm{C}$.

Tästä ei kuitenkaan, kuten luonnolliselta tuntuisi, välttämättä seuraa, että $u_{n}$ lähestyisi lauseketta $\mathrm{C}_{\varrho^{n}}$. Tämä ilmenee seuraavasta lyhyestä teoreettisesta tarkastelusta.

Lauseessa esitetyn väitteen tarkka matemaattinen ilmaisu on seuraava:

Olipa $\varepsilon$ miten pieni positiivinen kokonaisluku tahansa, on aina olemassa sellainen kokonaisluku $\mathrm{n}_{\varepsilon}$, että

2.2.9. $\left|\frac{\mathrm{u}_{\mathrm{n}}}{\varrho^{\mathrm{n}}}-\mathrm{C}\right|<\varepsilon$, kun $\mathrm{n}>\mathrm{n}_{\mathcal{E}}$, mistä välittömästi seuraa:

$-\varepsilon<\frac{\mathrm{u}_{\mathrm{n}}}{\varrho^{\mathrm{n}}}-\mathrm{C}<\varepsilon, \quad \mathrm{C}-\varepsilon<\frac{\mathrm{u}_{\mathrm{n}}}{\varrho^{\mathrm{n}}}<\mathrm{C}+\varepsilon$,

2.2.10. $C \varrho^{n}-\varepsilon \varrho^{n}<u_{n}<C \varrho^{n}+\varepsilon \varrho^{n}$.

Epäyhtälön 2.2.10. mukaan $u_{n}$ jatkuvasti poikkeaa lausekkeesta $C^{n}$ korkeintaan $\varepsilon \varrho^{\mathrm{n}}: \mathrm{n}$ verran. Tämän poikkeaman ei välttämättä tarvitse lähestyä nollaa, koska $\varepsilon$ voi tulla miten pieneksi, mutta $\varrho^{\mathrm{n}}$ miten suureksi tahansa. ${ }^{2}$

Lauseen 2 mukaan stabiili rajamuoto on pysyvä, ts. jos lähtöväestön ikäjakautuma on stabiili, se myös pysyy stabiilina, jos hedelmällisyys- ja eloonjäämisluvut pysyvät muuttumattomina. Niin ikään syntyneiden odotettu lukumäärä kasvaa jatkuvasti tarkkaan stabiilin kasvulain $\mathrm{C}_{\varrho^{\mathrm{n}}}$ mukaan.

1 Tämä on esimerkki todennäköisyyslaskennassa tunnetusta stokastisesta prosessista.

2 Itse asiassa $\varepsilon$ ja $\varrho^{\text {n }}$ riippuvat lähtöväestöstä $\left\{\mathrm{v}_{\mathrm{k}}(\mathrm{o})\right\}$, lukujonoista $\left\{\mathrm{c}_{\mathrm{k}}\right\}$ ja $\left\{\mathrm{r}_{\mathrm{k}}\right\}$ sekä n:stä. 


\section{Matemaattisen teorian sovellutus}

\subsection{Lauseista 1 ja 2 tehtäviä johtopäätöksiä}

Miten lähtöjakautuman ikäluokittaiset poikkeamat stabiilista ikäjakautumasta vaikuttavat odotetun syntyneisyyden poikkeamaan stabiilista kasvulaista $C_{Q^{\mathrm{n}}}$

Lauseet 1 ja 2 ilmaisevat matemaattisen väestömallimme kaksi oleellista ominaisuutta, odotetun ikäjakautuman stabiilin rajamuodon olemassaolon ja odotetun ikäjakautuman säilymisen stabiilina kuluneesta ajasta riippumatta, mikäli se alunperin on stabiili. Tätä taustaa vastaan herää luonnollinen kysymys: Kuinka nopeata ja minkä luonteista on lauseessa 1 mainittu asymptoottinen lähestyminen stabiilia rajamuotoa kohti, ts. kuinka nopeasti ja miten lähestyy k-vuotiaiden odotettu lukumäärä $v_{k}(n)$ lauseketta $\mathrm{Cr}_{\mathrm{k}} \varrho^{\mathrm{n}-\mathrm{k}}$ ja odotettu syntyneisyys $\mathrm{u}_{\mathrm{n}}$ stabiilia kasvulakia $\mathrm{C}_{\varrho^{n}}$, kun $\mathrm{n}$ kasvaa rajatta? Rajoitumme seuraavassa jälkimmäisen kysymyksen tarkasteluun.

Jotta voisimme käyttää hyväksi lausetta 2 jaamme k-vuotiaiden lukumäärän mielivaltaisessa lähtöjakautumassa $\left\{\mathrm{vk}_{\mathrm{k}}(\mathrm{o})\right\}$ kahteen osaan, stabiiliin osaan $\mathrm{Cr}_{\mathrm{k}} \varrho^{\mathrm{n}-\mathrm{k}}$ ja poikkeamaosaan $\delta_{\mathrm{k}}$, missä $\mathrm{C}$ on lauseessa 1 määritelty vakio:

3.1.1. $\mathrm{v}_{\mathrm{k}}(\mathrm{o})=\mathrm{Cr}_{\mathrm{k}} \varrho^{\mathrm{n}-\mathrm{k}}+\delta_{\mathrm{k}}$

Syntyneiden odotettu lukumäärä $u_{n}$ jakautuu vastaavasti stabiiliin osaan $\mathrm{C}_{Q^{\mathrm{n}}}$ ja poikkeamaosaan $\triangle \mathrm{u}_{\mathrm{n}}$. Siis

3.1.2. $u_{n}=C \varrho^{n}+\triangle u_{n}{ }^{1}$, mistä seuraa

3.1.3. $\Delta \mathrm{u}_{\mathrm{n}}=\mathrm{u}_{\mathrm{n}}-\mathrm{C} \varrho^{\mathrm{n}}$

Matemaattisesta teoriastamme voidaan johtaa seuraava esitysmuoto $\mathrm{u}_{\mathrm{n}}: l l e$ :

3.1.4. $\mathrm{u}_{\mathrm{n}} \underset{\mathrm{k}=0}{=} \frac{\mathrm{v}_{\mathrm{k}}(\mathrm{o})}{\mathrm{r}_{\mathrm{k}}} \cdot \mathrm{P}_{\mathrm{k}}^{\mathrm{n}} \quad$ missä

suureet $\mathrm{P} \underset{\mathrm{k}}{\mathrm{n}}$ määräytyvät rekursiivisesti yhtälöistä

${ }^{1} \triangle \mathrm{u}_{\mathrm{n}}$ on sama kuin $\varepsilon \varrho^{n}$ lauseeseen 1 liittyvässä petiitillä painetussa teoreettisessa tarkastelussa. 


$$
\begin{aligned}
& \mathrm{P}_{\mathrm{k}}^{1}=\mathrm{c}_{\mathrm{k}+1} \\
& \mathrm{P}_{\mathrm{k}}^{2}=\mathrm{c}_{\mathrm{k}+2}+\mathrm{c}_{1} \mathrm{P}_{\mathrm{k}}^{1} \\
\text { 3.1.5. } & \mathrm{P}_{\mathrm{k}}^{3}=\mathrm{c}_{\mathrm{k}+3}+\mathrm{c}_{2} \mathrm{P}_{\mathrm{k}}^{1}+\mathrm{c}_{1} \mathrm{P}_{\mathrm{k}}^{2} \\
& \frac{\mathrm{P}_{\mathrm{k}}^{\mathrm{n}}}{\mathrm{k}}=\mathrm{c}_{\mathrm{k}+\mathrm{n}}+\mathrm{c}_{\mathrm{n}-1} \mathrm{P}_{\mathrm{k}}^{1}+\mathrm{c}_{\mathrm{n}-2} \mathrm{P}_{\mathrm{k}}^{2}+\ldots \ldots+\mathrm{c}_{1} \mathrm{P}_{\mathrm{k}}^{\mathrm{n}-1}
\end{aligned}
$$

Yhtälöistä 3.1.3., 3.1.4. ja 3.1.5. seuraa, että mille tahansa empiirisesti annetulle lähtöjakautumalle $\left\{\mathrm{v}_{\mathrm{k}}(\mathrm{o})\right\}$ sekä hedelmällisyyslukujonolle $\left\{\mathrm{c}_{\mathrm{k}}\right\}$ ja eloonjäämislukujonolle $\left\{\mathrm{r}_{\mathrm{k}}\right\}$ voidaan laskea odotettu syntyneiden lukumäärä $u_{n}$ ja syntyneisyyspoikkeama $\triangle u_{n}$. Kun lisäksi jokaisella n:n arvolla on olemassa omat $c_{k}$-polynominsa $P_{k}^{n}$, jotka voidaan etukäteen laskea valmiiksi, on mahdollista määrätä $u_{n}$ ja $\triangle u_{n}$ millä $n: n$ arvoväleillä tahansa (esim. vaikka suoraan n:n arvolle 50 ).

Kohdassa 3.2. sovellamme yhtälöitä 3.1.3., 3.1.4. ja 3.1.5. Suomen naispuoliseen väestöön 31/12 1955 .

3.2. Suomessa syntyvien tyttölasten odotettu ja stabiilin kasvulain mukainen lukumäärä sekä syntyneisyyspoikkeama v. 1960-2005.

Kuten aikaisemmin esityksen kuluessa on todettu, on luvuilla $\mathrm{r}_{\mathrm{k}}, \beta_{\mathrm{k}}$ ja $\mathrm{c}_{\mathrm{k}}$ tunnetut demografiset vastineet:

3.2.1. $\mathrm{r}_{\mathrm{k}}=\frac{\text { naisten eloonjäämisluku } \mathrm{l}_{\mathrm{k}}{ }^{1}}{\text { juuri } \mathrm{l}_{\mathrm{o}}}$

3.2.2. $\beta_{\mathrm{k}}=\frac{\mathrm{k} \text {-vuotiaille naisille } \mathrm{n} \text {-vuotiskautena syntyneiden tyttölasten luku }}{\mathrm{n} \cdot(\mathrm{k} \text {-vuotiaitten naisten keskiväkiluku } \mathrm{n} \text {-vuotiskautena })}=$

$=$ naisten brutto-erikoishedelmällisyysluku

3.2.3. $\mathrm{c}_{\mathrm{k}}=$ naisten netto-erikoishedelmällisyysluku

Taulussa 1 esitetään maamme naispuolisen $0-49$-vuotiaan väestön ikäjakautuma 31/12 $1955\left\{\mathrm{v}_{\mathrm{k}}(\mathrm{o})\right\}$ sekä vuosien 1951-55 syntyneisyyteen ja kuolleisuuteen perustuvat $\mathrm{r}_{\mathrm{k}^{-}}, \beta_{\mathrm{k}^{-}}{ }^{2}$ ja $\mathrm{c}_{\mathrm{k}}$-luvut.

1 Tämä vastaavaisuus ei ole aivan tarkka, koska $1_{k}$ on tarkassa iässä $\mathrm{k}$ elossa olevien luku, kun taas $r_{k}$ tarkoittaa todennäköisyyttä olla elossa iässä, joka on $1 / 2$ vuotta k:nnen syntymäpäivän molemmin puolin. (Vrt. määritelmiä kohdan 2.1. alussa). Kuitenkin lienevät ylläesitetyt $\mathrm{r}_{\mathrm{k}}: \mathrm{n}$ ja $\beta_{\mathrm{k}}: \mathrm{n}$ estimaatit riittävän tarkkoja odotetun syntyneisyyden kehityssuunnan määräämiseen. kausi).

2 Perusparametri $\beta_{\mathrm{k}}$ on laskettu yhtälöstä 3.2.2. käyttämällä n:n arvoa 5 (5-vuotis- 
Taulu 1. Perusparametrit $\mathrm{v}_{\mathrm{k}}(\mathrm{o}), \mathrm{r}_{\mathrm{k}}, \beta_{\mathrm{k}}$ ja $\mathrm{c}_{\mathrm{k}}$.

Table 1. The primary parameters $v_{\mathrm{k}}(o), r_{\mathrm{k}}, \beta_{\mathrm{k}}$ and $\mathrm{c}_{\mathrm{k}}$.

\begin{tabular}{|c|c|c|c|c|}
\hline $\mathrm{k}$ & $\mathrm{v}_{\mathrm{k}}(\mathrm{o})$ & $r_{k}$ & $\beta_{\mathrm{k}}$ & $c_{k}$ \\
\hline 0 & 42749 & 1.00000 & - & - \\
\hline 1 & 42892 & 0.97175 & - & - \\
\hline 2 & 42822 & 0.96899 & - & - \\
\hline 3 & 44331 & 0.96763 & - & - \\
\hline 4 & 43516 & 0.96657 & - & - \\
\hline 5 & 46160 & 0.96578 & - & - \\
\hline 6 & 48047 & 0.96506 & - & - \\
\hline 7 & 49977 & 0.96449 & - & - \\
\hline 8 & 49880 & 0.96400 & - & - \\
\hline & 49225 & 0.96353 & - & - \\
\hline 10 & 44206 & 0.96313 & - & - \\
\hline 11 & 35941 & 0.96275 & - & - \\
\hline 12 & 34242 & 0.96234 & - & - \\
\hline 13 & 28223 & 0.96183 & - & - \\
\hline 14 & 40585 & 0.96133 & - & - \\
\hline 15 & 29611 & 0.96082 & 0.0000369506 & 0.000035503 \\
\hline 16 & 34981 & 0.96028 & 0.000759042 & 0.000728890 \\
\hline 17 & 33672 & 0.95968 & 0.005462310 & 0.005242100 \\
\hline 18 & 32022 & 0.95898 & 0.017420600 & 0.016706000 \\
\hline 19 & 30809 & 0.95808 & 0.033621500 & 0.032212000 \\
\hline 20 & 30780 & 0.95721 & 0.050360900 & 0.048206000 \\
\hline 21 & 30038 & 0.95620 & 0.064125000 & 0.061316000 \\
\hline 22 & 28407 & 0.95514 & 0.076112000 & 0.072698000 \\
\hline 23 & 30369 & 0.95415 & 0.082058800 & 0.078296000 \\
\hline 24 & 30869 & 0.95293 & 0.084083700 & 0.080126000 \\
\hline 25 & 32564 & 0.95183 & 0.083228100 & 0.079219000 \\
\hline 26 & 32202 & 0.95072 & 0.081860800 & 0.077770000 \\
\hline 27 & 31927 & 0.94948 & 0.079066500 & 0.075072000 \\
\hline 28 & 30918 & 0.94818 & 0.074307700 & 0.070457000 \\
\hline 29 & 31060 & 0.94669 & 0.070298800 & 0.066551000 \\
\hline 30 & 31829 & 0.94517 & 0.068213100 & 0.064473000 \\
\hline 31 & 31205 & 0.94365 & 0.062850100 & 0.059308000 \\
\hline 32 & 32129 & 0.94214 & 0.058823900 & 0.055420000 \\
\hline 33 & 30943 & 0.94049 & 0.054049700 & 0.050833000 \\
\hline 34 & 31868 & 0.93881 & 0.051440800 & 0.048293000 \\
\hline 35 & 32597 & 0.93697 & 0.046576900 & 0.043641000 \\
\hline 36 & 24057 & 0.93512 & 0.042313800 & 0.039568000 \\
\hline 37 & 28729 & 0.93318 & 0.038994300 & 0.036389000 \\
\hline 38 & 28420 & 0.93108 & 0.033987900 & 0.031645000 \\
\hline 39 & 27597 & 0.92891 & 0.030472100 & 0.028306000 \\
\hline 40 & 28603 & 0.92681 & 0.026560800 & 0.024617000 \\
\hline 41 & 29895 & 0.92463 & 0.021009900 & 0.019426000 \\
\hline 42 & 29785 & 0.92192 & 0.017023300 & 0.015694000 \\
\hline 43 & 31071 & 0.91938 & 0.011662500 & 0.010722000 \\
\hline 44 & 30474 & 0.91665 & 0.007404630 & 0.006787500 \\
\hline 45 & 30705 & 0.91374 & 0.004345840 & 0.003971000 \\
\hline 46 & 30869 & 0.91058 & 0.002189460 & 0.001993700 \\
\hline 47 & 29684 & 0.90683 & 0.001150500 & 0.001043300 \\
\hline 48 & 29710 & 0.90308 & 0.001103690 & 0.000996720 \\
\hline 49 & 28616 & 0.89908 & 0.000182786 & 0.000164340 \\
\hline
\end{tabular}


Taulu 2. Syntyneiden odotetun lukumäärän $u_{n}$ määrääminen.

Table 2. The determination of the expected number of births $u_{\mathrm{n}}$.

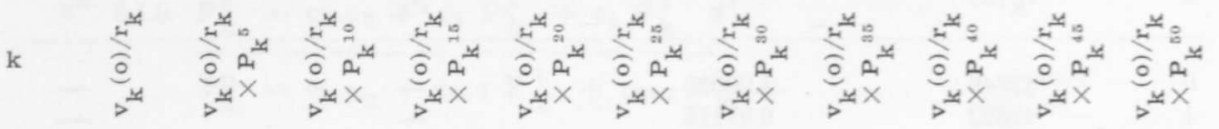

\begin{tabular}{|c|c|c|c|c|c|c|c|c|c|}
\hline 42749 & - & - & 2 & 2061 & 3387 & 2756 & 1875 & 1465 & 1760 \\
\hline 44139 & - & - & 32 & 2706 & 3433 & 2618 & 1777 & 1483 & 1985 \\
\hline 44192 & - & - & 231 & 3213 & 3318 & 2449 & 1682 & 1552 & 2184 \\
\hline 45814 & - & - & 766 & 3587 & 3227 & 2329 & 1606 & 1646 & 2486 \\
\hline 45021 & - & - & 1450 & 3608 & 2996 & 2177 & 1546 & 1710 & 2602 \\
\hline 47795 & - & 2 & 2304 & 3787 & 3081 & 2097 & 1638 & 1968 & 2934 \\
\hline 49787 & - & 36 & 3053 & 3872 & 2953 & 2004 & 1672 & 2239 & 3212 \\
\hline 51817 & - & 272 & 3767 & 3890 & 2872 & 1972 & 1821 & 2561 & 3474 \\
\hline 51743 & - & 864 & 4051 & 3645 & 2631 & 1813 & 1859 & 2808 & 3568 \\
\hline 51088 & - & 1646 & 4093 & 3400 & 2470 & 1754 & 1941 & 2953 & 3592 \\
\hline 45898 & 2 & 2213 & 3636 & 2959 & 2013 & 1573 & 1890 & 2818 & 3262 \\
\hline 37332 & 27 & 2289 & 2903 & 2214 & 1503 & 1255 & 1679 & 2409 & 2663 \\
\hline 35582 & 186 & 2586 & 2672 & 1972 & 1354 & 1250 & 1758 & 2386 & 2532 \\
\hline 29343 & 490 & 2298 & 2068 & 1492 & 1028 & 1054 & 1593 & 2024 & 2071 \\
\hline 42218 & 1360 & 3383 & 2810 & 2041 & 1450 & 1604 & 2440 & 2968 & 2942 \\
\hline 30819 & 1485 & 2442 & 1987 & 1352 & 1056 & 1269 & 1892 & 2191 & 2112 \\
\hline 36428 & 2234 & 2832 & 2161 & 1465 & 1222 & 1636 & 2349 & 2598 & 2445 \\
\hline 35087 & 2551 & 2634 & 1944 & 1325 & 1216 & 1720 & 2343 & 2489 & 2296 \\
\hline 33392 & 2614 & 2352 & 1698 & 1130 & 1140 & 1764 & 2270 & 2332 & 2110 \\
\hline 32157 & 2577 & 2140 & 1553 & 1007 & 1083 & 1749 & 2187 & 2180 & 1938 \\
\hline 32156 & 2547 & 2073 & 1403 & 909 & 1067 & 1773 & 2149 & 2089 & 1825 \\
\hline 31414 & 2443 & 1863 & 1243 & 740 & 1017 & 1721 & 2032 & 1932 & 1659 \\
\hline 29741 & 2233 & 1648 & 1083 & 596 & 937 & 1587 & 1837 & 1707 & 1442 \\
\hline 31828 & 2243 & 1618 & 1007 & 480 & 982 & 1631 & 1856 & 1684 & 1401 \\
\hline 32394 & 2155 & 1565 & 917 & 359 & 939 & 1577 & 1768 & 1565 & 1286 \\
\hline 34212 & 2205 & 1493 & 843 & 278 & 942 & 1573 & 1734 & 1494 & 1215 \\
\hline 33871 & 2009 & 1340 & 658 & 203 & 885 & 1458 & 1578 & 1323 & 1068 \\
\hline 33626 & 1863 & 1224 & 528 & 161 & 826 & 1347 & 1427 & 1165 & 936 \\
\hline 32608 & 1658 & 1031 & 350 & 149 & 752 & 1211 & 1250 & 993 & 797 \\
\hline 32809 & 1584 & 928 & 223 & 117 & 708 & 1121 & 1124 & 873 & 701 \\
\hline 33675 & 1470 & 829 & 133 & 106 & 671 & 1046 & 1016 & 772 & 623 \\
\hline 33068 & 1309 & 642 & 66 & 96 & 608 & 927 & 869 & 649 & 527 \\
\hline 34102 & $1:$ & 535 & 36 & 92 & 574 & 852 & 772 & 567 & 464 \\
\hline 32901 & 1041 & 353 & 33 & 83 & 505 & 723 & 632 & 458 & 381 \\
\hline 33945 & 961 & 230 & 5 & 78 & 467 & 642 & 543 & 390 & 328 \\
\hline 34790 & 856 & 138 & - & 72 & 424 & 556 & 458 & 326 & 279 \\
\hline 6 & 499 & 51 & - & 48 & 273 & 340 & 273 & 192 & 168 \\
\hline 30786 & 483 & 32 & - & 50 & 276 & 326 & 256 & 180 & 161 \\
\hline 30524 & 328 & 30 & - & 44 & 226 & 252 & 194 & 136 & 125 \\
\hline 297 & 201 & 5 & - & 36 & 172 & 183 & 140 & 97 & 92 \\
\hline 30862 & 123 & - & - & 29 & 132 & 135 & 101 & 70 & 68 \\
\hline 32332 & 65 & - & - & 24 & 96 & 95 & 71 & 50 & 49 \\
\hline 32307 & 34 & - & - & 15 & 61 & 59 & 43 & 30 & 30 \\
\hline 33796 & 34 & - & - & 10 & 38 & 36 & 26 & 18 & 18 \\
\hline ת & 5 & - & - & 5 & 21 & 19 & 14 & 10 & 10 \\
\hline 33604 & - & - & - & 3 & 11 & 10 & 8 & 5 & 5 \\
\hline & - & - & - & 2 & 5 & 5 & 3 & 2 & 3 \\
\hline & - & - & - & 1 & 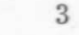 & 2 & 2 & 1 & 1 \\
\hline 32898 & - & - & - & - & - & - & - & - & - \\
\hline
\end{tabular}


Taulu 3. Syntyneiden odotettu lukumäärä $u_{n}$, stabiilin kasvulain mukainen syntyneiden määrä $C_{\varrho^{n}}$ ja syntyneisyyspoikkeama $\triangle u_{n}$.

Table 3. The expected number of births $u_{\mathrm{n}}$, the number of births according to the stable law of growth $\mathrm{C}_{\varrho^{n}}$, and the birth deviation $\triangle u_{\mathrm{n}}$.

\begin{tabular}{rccc}
\hline $\mathrm{n}$ & $\mathrm{u}_{\mathrm{n}}$ & $\mathrm{C} \varrho \mathrm{n}$ & $\Delta \mathrm{u}_{\mathrm{n}}$ \\
\hline 5 & 43116 & 46215 & -3099 \\
10 & 45617 & 48442 & -2825 \\
15 & 51709 & 50775 & +934 \\
20 & 55512 & 53220 & +2292 \\
25 & 57051 & 55783 & -1268 \\
30 & 58050 & 58470 & -1293 \\
35 & 59994 & 61287 & -681 \\
40 & 63558 & 64239 & +498 \\
45 & 67830 & 67332 & +942 \\
50 & 71517 & 70575 & \\
\hline
\end{tabular}

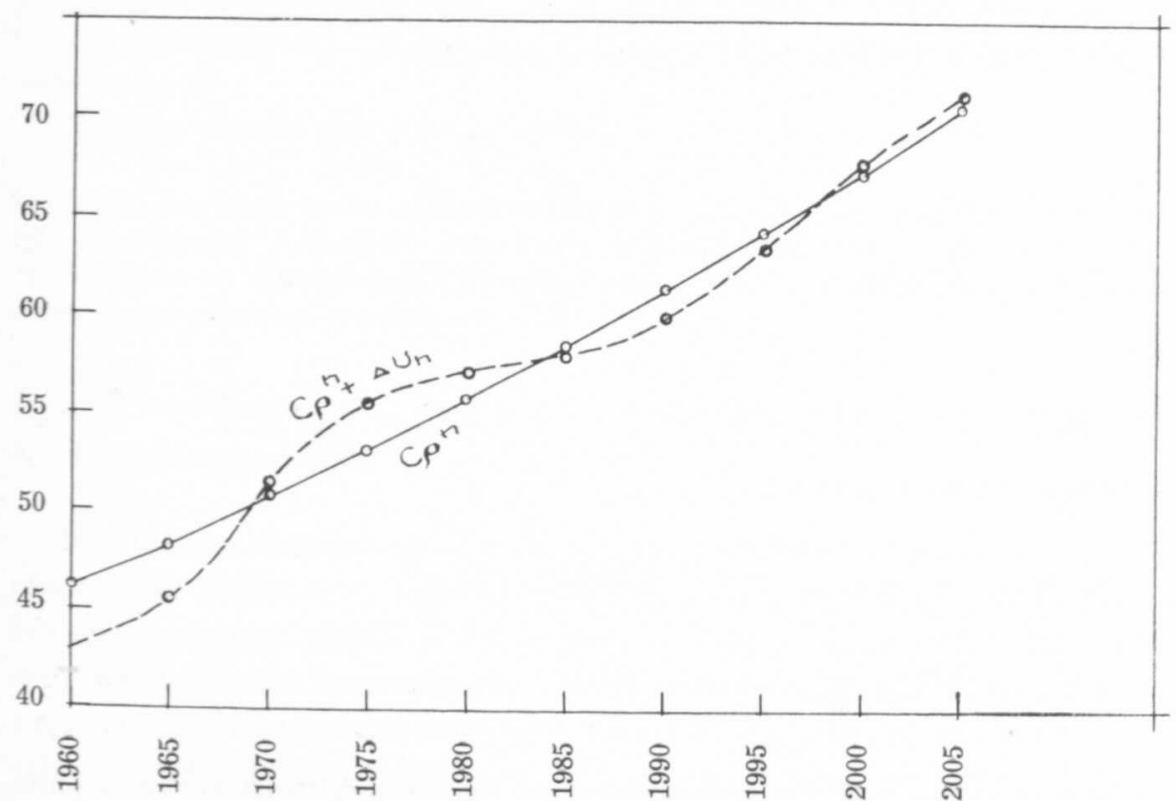

Kuvio 1. Suomessa v. 1960-2005 syntyvien tyttölasten odotettu (- - -) ja stabiilin kasvulain mukainen (-) lukumäärä.

Figure 1. The expected number of female births (- - ) and the number of female births according to the stable law of growth (-) in Finland during the years 1960-2005. 
Tarvittavat $\mathrm{P}_{\mathrm{k}}^{\mathrm{n}}$ - ja $\varrho^{\mathrm{n}}$-luvut on laskettu elektronilaskukoneilla ${ }^{1}$ (IBM 1620 ja ESKO). Vakion C arvoksi on saatu yhtälöstä 2.2.5. 44093 , $\varrho: n$ arvoksi 1.009452436. Luvut $\mathrm{u}_{\mathrm{n}}, \mathrm{C} \varrho^{\mathrm{n}}$ ja $\triangle \mathrm{u}_{\mathrm{n}}$ on laskettu n:n arvoilla 5, $10,15,20,25,30,35,40,45,50$, kuten tauluista 2 ja 3 ilmenee ${ }^{2}$.

Taulussa 3. esitetyt lopputulokset on havainnollistettu kuviossa 1, josta ilmenee, että syntyneisyyspoikkeama $\triangle u_{n}$ pienenee itseisarvoltaan lyhyellä tähtäimellä likimäärin vaimenevaa aaltoliikettä seuraten. Pidettäessä stabiilia väestöä normaaliolotilana, on positiivinen $\triangle u_{n}$ lähtöväestön runsasväkisestä (stabiilia suuremmasta) ikäpolvesta aiheutuva syntyneisyysylijäämä ja negatiivinen $\triangle u_{n}$ lähtöväestön vähäväkisestä (stabiilia pienemmästä) ikäpolvesta aiheutuva syntyneisyysalijäämä. Eilert Sundtin laki saa siis matemaattisen mallimme puitteissa seuraavan muodon: Runsasväkisestä ikäpolvesta aiheutuva syntyneisyysylijäämä ja vähäväkisestä ikäpolvesta aiheutuva syntyneisyysalijäämä toistuu lyhyellä tähtäimellä likimäärin jaksollisesti mutta jatkuvasti vaimenevana.

Yhtälöiden 3.1.3.-5. perusteella voidaan edellä empiirisesti todettu syntyneisyyspoikkeaman $\Delta u_{n}$ vaimeneva jaksollisuus todistaa yleispätevästi siinä epärealistisessa erikoistapauksessa, että väestöön kuuluvilla naisilla on vain yksi hedelmällisyysikä $\mathrm{m}$, ts. $c_{m} \# 0, c_{1}=c_{2}=\ldots \ldots . . .=c_{m-1}=c_{m+1}=c_{m+2}=\ldots \ldots . .$.

Yhtälöistä 3.1.5. ja tehdyistä olettamuksista seuraa tällöin:

$$
\begin{aligned}
& \mathrm{P}_{\mathrm{m}-1}^{1}=\mathrm{P}_{\mathrm{m}-2}^{2}=\ldots \ldots \ldots . . .=\mathrm{P}_{\mathrm{o}}^{\mathrm{m}}=\mathrm{c}_{\mathrm{m}} \\
& \mathrm{F}_{\mathrm{m}-1}^{\mathrm{m}+1}=\mathrm{P}_{\mathrm{m}-2}^{\mathrm{m}+2}=\ldots \ldots \ldots . . .=\mathrm{P}_{\mathrm{o}}^{2 \mathrm{~m}}=\mathrm{c}_{\mathrm{m}} \mathrm{P}_{\mathrm{m}-1}^{1}=\mathrm{c}_{\mathrm{m}}^{2} \\
& \mathrm{P}_{\mathrm{m}-1}^{2 \mathrm{~m}+1}=\mathrm{P}_{\mathrm{m}-2}^{2 \mathrm{~m}+2}=\ldots \ldots \ldots \ldots=\mathrm{P}_{\mathrm{o}}^{3 \mathrm{~m}}=\mathrm{c}_{\mathrm{m}} \mathrm{P}_{\mathrm{m}-1}^{\mathrm{m}+1}=\mathrm{c}_{\mathrm{m}}^{3}
\end{aligned}
$$

ja yleisesti

3.2.4. $\mathrm{P}_{\mathrm{m}-1}^{(\mu-1) \mathrm{m}+1}=\mathrm{P}_{\mathrm{m}-2}^{(\mu-1) \mathrm{m}+2}=\ldots \ldots . .=\mathrm{P}_{\mathrm{o}}^{\mu \mathrm{m}}=\mathrm{c}_{\mathrm{m}} \mathrm{P}_{\mathrm{m}-1}^{(\mu-2) \mathrm{m}+1}=\mathrm{c}_{\mathrm{m}}^{\mu}$

Yhtälön 3.1.4. mukaan on siis

$$
\begin{aligned}
& \mathrm{u}_{\mathrm{m}-\mathrm{k}}=\frac{\mathrm{v}_{\mathrm{k}}(\mathrm{o})}{\mathrm{r}_{\mathrm{k}}} \mathrm{c}_{\mathrm{m}} \quad(0 \leqq \mathrm{k} \leqq \mathrm{m}-1 ; \mu \geqq 1) \\
& \mathrm{u}_{2 \mathrm{~m}-\mathrm{k}}=\frac{\mathrm{v}_{\mathrm{k}}(\mathrm{o})}{\mathrm{r}_{\mathrm{k}}} \mathrm{c}_{\mathrm{m}}^{2}
\end{aligned}
$$

1 Myös tauluissa 2 ja 3 esiintyvät laskelmat (jopa mahdollisesti kuvion 1 piirtäminen) voidaan ohjelmoida elektronikoneille. Tässä tutkimuksessa on kuitenkin kustannusten rajoittamiseksi tyydytty käyttämään mainittuja koneita vain kaikkein raskaimpaan laskutyöhön ( $\mathrm{P}_{\mathbf{k}}^{\mathrm{n}}-$ ja $\varrho^{\mathrm{n}-l u k u j e n ~ m a ̈ a ̈ r a ̈ a ̈ m i s e e n .) . ~}$

2 Laskelmissa muodostuu huomattavia pyöristysvirheitä, mutta siitä huolimatta voitaneen lukuja taulussa 3 pitää kehityssuuntaa ilmaisevina. 
ja yleisesti

3.2.5. $\mathrm{u}_{\mu \mathrm{m}-\mathrm{k}}=\frac{\mathrm{v}_{\mathrm{k}}(\mathrm{o})}{\mathrm{r}_{\mathrm{k}}} \mathrm{c}_{\mathrm{m}}^{\mu}$

Kasvutekijä $\varrho$ on yhtälön $\mathrm{c}_{\mathrm{m}} \mathrm{s}^{\mathrm{m}}=1$ (vrt. lause 1) pienimmän positiivisen juuren käänteisarvo, joten

$\varrho=c_{m}^{\frac{1}{m}}$

Stabiilin kasvulain lauseke saa siis tässä tapauksessa muodon

3.2.6. $\mathrm{C} e^{\mu \mathrm{m}-\mathrm{k}}=\mathrm{Cc}_{\mathrm{m}}{ }^{\mu \frac{\mu \mathrm{m}-\mathrm{k}}{\mathrm{m}}}=\mathrm{Cc}_{\mathrm{m}}^{\mu-\frac{\mathrm{k}}{\mathrm{m}}}$

Yhtälöiden 3.2.5., 3.2.6. ja 3.1.3. perusteella on vihdoin

$$
\begin{aligned}
& \Delta \mathrm{u}_{\mu \mathrm{m}-\mathrm{k}}=\mathrm{u}_{\mu \mathrm{m}-\mathrm{k}}-\mathrm{C}_{\varrho}{ }^{\mu \mathrm{m}-\mathrm{k}}= \\
& =\frac{\mathrm{v}_{\mathrm{k}}(\mathrm{o})}{\mathrm{r}_{\mathrm{k}}} \mathrm{c}_{\mathrm{m}}^{\mu}-\mathrm{Cc}_{\mathrm{m}}^{\mu-\frac{\mathrm{k}}{\mathrm{m}}}= \\
& =\mathrm{c}_{\mathrm{m}}^{\mu-\frac{\mathrm{k}}{\mathrm{m}}}\left(\frac{\mathrm{v}_{\mathrm{k}}(\mathrm{o})}{\mathrm{r}_{\mathrm{k}}} \mathrm{c} \mathrm{m}^{\frac{\mathrm{k}}{\mathrm{m}}}-\mathrm{C}\right) .
\end{aligned}
$$

Viimeksi saadusta lausekkeesta ilmenee, että kunkin kalenterivuoden syntyneisyyspoikkeamaan vaikuttaa vain yksi k-vuotiaiden ikäluokka. Kunkin ikäluokan aiheuttama syntyneisyyspoikkeama toistuu siis $\mathrm{m}$ vuoden jaksoin kerrottuna vaimennuskertoimella $\mathrm{c}_{\mathrm{m}}$.

Todistus yleiselle tapaukselle, jolloin on kyseessä hedelmällisyysikäväli $\mathrm{m}, \mathrm{m}+1$, $\ldots \ldots \ldots, \mathrm{m}+\mathrm{p}$, on paljon mutkikkaampi. Mutta jos oletamme, että hedelmällisyys keskittyy läheisesti tietyn ikävuoden m ympärille, seuraa syntyneisyyspoikkeaman likimääräinen ja vaimeneva jaksollisuus lyhyellä tähtäimellä yleisessä tapauksessa erikoistapauksen todistuksesta. Tätä ei voi pitää tarkkana päättelynä, mutta väitteen oikeus tuntuu kuitenkin todennäköiseltä.

\section{Lopputoteamuksia}

Koska käytännössä hedelmällisyys ja kuolleisuus muuttuvat varsin nopeasti ajan mukana, ei esitetty matemaattinen väestömalli ole sopiva edes lähiajan syntyneisyyden ennustamiseen. Tulee lähinnä mieleen yrittää seuraavan tapaista menetelmää. ${ }^{1}$ Koetetaan kuvailla perustavat lukujonot $\left\{\mathrm{a}_{\mathrm{i}}\right\}$ ja $\left\{\beta_{\mathrm{j}}\right\}$ muutamien harvojen tunnuslukujen avulla; voimme ajatella esim. toiselta puolen kuoliniän keskiarvoa ja hajontaa, toiselta puolen lasten keskilukumäärää sekä synnytysiän keskiarvoa ja hajontaa. Stabiilissa mallissa ennustusarvot $\mathrm{u}_{\mathrm{n}} \mathrm{ja} \mathrm{v}_{\mathrm{k}}(\mathrm{n})$ riippuvat lukujonoista $\left\{\mathrm{a}_{\mathrm{i}}\right\}$ ja $\left\{\beta_{\mathrm{j}}\right\}$ ja ensisijassa - otaksuttavasti - niiden yllämainituista tunnusluvuista.

1 Tämä idea on prof. Elfvingin esittämä. 
Jos tunnuslukujen kehityssuunta on arvioitavissa, on myös tämän kehityksen vaikutus ennustusarvoihin laskettavissa. Näin voidaan mahdollisesti päästä realistisempaan syntyneisyyden ennustamiseen.

Toinen kohdassa 2 esitetyn väestömallin puute on, että satunnaisia poikkeamia hedelmällisyyden ja kuolleisuuden odotetusta kehityksestä ei ole otettu huomioon. ${ }^{1}$ Todennäköisyyslaskennan pitemmälle kehitettyä teoriaa soveltamalla voidaan konstruoida satunnaispoikkeamat huomioon ottava malli, mutta se lienee käytännöllisten laskelmien kannalta liian monimutkainen.

Kolmas puute on olettamus, että väestössä on tarpeeksi miehiä. Onhan historia toistuvasti osoittanut, että ennenkaikkea sodat vähentävät naimaikäisten miesten lukumääriä.

Myönteisenä piirteenä voidaan mainita, että kohdassa 2 esitetty väestömalli yleisen muotonsa ansiosta saattaa muodollisen demografian luonnolliseen yhteyteen matemaattisen biologian kanssa. ${ }^{2}$

Kohdassa 3.2. havaittu syntyneisyyspoikkeaman likimääräinen vaimeneva jaksollisuus johtaa helposti ajatukseen approksimoida mainittua poikkeamaa muotoa

4.1. $\mathrm{a}_{0}+\sum_{\nu=1}^{\infty}\left(\mathrm{a}_{\nu} \cos \nu \mathrm{t}+\mathrm{b}_{\nu} \sin \nu \mathrm{t}\right) \mathrm{e}^{-\mathrm{c}_{\nu} \mathrm{t} 2}$

olevalla lausekkeella. Todellisessa väestössä haivaittava syntyneisyyspoikkeaman aaltoliike on tällöin esitetty usean kohdan 3.2. tapaisen vaimenevan aaltoliikkeen resultanttina. Vastaavanlaista menettelyä on tiettävästi sovellettu taloudellisiin aikasarjoihin. (Kendall II, s. 423-435).

\section{Kirjallisuutta}

\section{EILERT SUNDTIN LAKI:}

Kilpi, O. K. Suomen ammatissatoimiva väestö ja sen yhteiskunnalliset luokat vuosina 1815/1875. I. Helsinki 1913.

Lento, Reino. Väestö ja hyvinvointi. Johdatusta väestötieteeseen. Porvoo 1956.

Lösch, A. Bevölkerungswellen und Wechsellagen. Jena 1936.

Sundbärg, Gustav. Bevölkerungsstatistik Schwedens 1750-1900. Stockholm 1907.

Sundt, Eilert. Om giftermaal i Norge. Kristiania 1855.

1 Jos jonkin ajasta riippuvan todennäköisyysmallin varianssin voidaan osoittaa kasvavan rajatta, menettää koko malli arvonsa.

2 Teorian tunnettu esittäjä $A$. J. Lotka oli matetaattinen biologi.

3 Jos e-ert $=1$, on kysymysessä Fourier'n sarja. 
STABIILI VÄESTÖ, MUODOLLISTA DEMOGRAFIAA:

Barclay, George W. Techniques of Population Analysis. Princeton, N.J., 1958.

Dublin, L. I. ja Lotka, Alfred J. On the True Rate of Natural Increase as Exemplified by the Population of the U.S.A. 1920. Journal of the American Statistical Association. September 1925.

Lotka, Alfred J. The Stability of the Normal Age Distribution. Proceedings of the National Academy of Sciences of the U.S.A. Vol. 8, 1922.

Törnqvist, Leo. En befolkningsstatistisk jämförelse mellan Finland och Sverige. Ekonomiska Samfundets Tidskrift 3, 1948.

\title{
HARMONINEN ANALYYSI SOVELLETTUNA AIKASARJOIHIN:
}

Kendall, Maurice G. The Advanced Theory of Statistics. Vol. II. London 1951.

\section{Summary:}

\section{A Mathematical Interpretation of the Concept of the Stable Population and Eilert Sundt's Law}

\author{
By HEIKKI LAUTKARI \\ Central Statistical Office of Finland
}

By this summary is described an article which in itself constitutes an abridgment of the author's paper written for obtaining the mark of Laudatur in Statistics at the University of Helsinki. The subject for the investigation was suggested to me by Prof. G. Elfving of Helsinki, who also has given valuable advice during its performance.

The work consists of four main sections: a demographic background, the mathematical theory itself, an application of it, and finally, a discussion of the applicability of the theory.

As background are given the traditional definitions of the concepts of life table, stationary population and stable population. Moreover, the first part contains a statement of the law of periodical changes in the number of annual human births (Eilert Sundt's law).

In the second part a mathematical theory of the stable population is advanced, however without mathematical derivations. The primary parameters, variables and equations are introduced, together with two fundamental theorems. The first of these establishes the stable population as the limit of the age distribution of a female population, and the stable law of growth $(\mathrm{C} \varrho \mathrm{n})^{1}$ as the limit form of the expected number $u_{n}$ of annual female births, providing that the birth and death rates by one-year age groups per years of life are assumed to be constant. The second theorem proves the permanence of the stable population, which implies the following: if the starting population is stable, and the annual birth and death rates per year of life are assumed to be constant, the population and the growth of the number of annual female births keep stable.

1 The symbol $\varrho$ indicates the true rate of natural increase, introduced by A. J. Lotka. The symbol $\mathrm{C}$ is a constant. 
After this, in application of the above-mentioned fundamental theorems, are presented a number of formulas $(3.1 .3 .-3.1 .5)$ for calculating the expected number $u_{n}$ of births and the birth excess or birth deficit $\Delta u_{n}$ caused by the deviation of the real starting population from the corresponding stable population. These formulas are in 3.2. applied to the female population of Finland at the end of 1955, in which connection it is assumed to develop according to the birth and death rates of the years $1951-55 .^{2}$ In the birth excess and deficit of the years 1960-2005 an approximately decreasing periodic movement can be clearly distinguished. This observation is in keeping with Eilert Sundt's law of the conditions above referred to. At the same point a mathematical verification is given of this law, under the schematic assumption that there exists only one fertility age $\mathrm{m}$.

The fourth part of the article offers a criticism of the mathematical theory in its beginning, which runs in broad outline as follows: Birth and death rates never keep constant in real life. A population does not always contain enough males. Random deviations from the expected number of births ought to be taken into account as well when building up the theory comtemplated. Some suggestions are made, however, for its improvement, as e.g. that, to search for a good approximate expression for the dependence of the expected number of births on certain appropriate parameters that govern the birth and death rates. Another idea proposed is, to approximate the real birth excess and birth deficit by means of a damped Fourier series (4.1.). In any case, the general form of the theory as given in part 2 shows the natural interrelation between formal demography and mathematical biology.

2 The primary parameters in table 1 mean as follows: The symbol $\mathrm{v}_{\mathrm{k}}(0)$ is the number of people $\mathrm{k}$ years of age in the starting population, $\mathrm{r}_{\mathrm{k}}$ is the number of survivors according to the life table, $\beta_{\mathrm{k}}$ is the gross fertility rate and $c_{\mathrm{k}}$ the net fertility rate, all calculated for the years $1951-55$. The symbol $\mathrm{P}_{\mathrm{k}}^{\mathrm{n}}$ in table 2 is defined by the equations 3.1.5. in the article. 